\title{
"Problems and perspectives for attracting investments in economy of Ukraine"
}

\begin{tabular}{|c|c|}
\hline \multirow{5}{*}{ AUTHORS } & Ivan Bogatyrev (D) https://orcid.org/0000-0003-4001-7256 \\
\hline & Vasyl Topchiy (D https://orcid.org/0000-0002-1726-9028 \\
\hline & Igor Koropatnik (D https://orcid.org/0000-0002-0493-0710 \\
\hline & Oleksandr Kotliarenko (D) https://orcid.org/0000-0001-8776-2515 \\
\hline & Andrii Kofanov (D) https://orcid.org/0000-0002-5242-2518 \\
\hline ARTICLE INFO & $\begin{array}{l}\text { Ivan Bogatyrev, Vasyl Topchiy, Igor Koropatnik, Oleksandr Kotliarenko and } \\
\text { Andrii Kofanov (2019). Problems and perspectives for attracting investments in } \\
\text { economy of Ukraine. Investment Management and Financial Innovations, 16(2), } \\
\text { 195-205. doi:10.21511/imfi.16(2).2019.17 }\end{array}$ \\
\hline DOI & http://dx.doi.org/10.21511/imfi.16(2).2019.17 \\
\hline RELEASED ON & Thursday, 06 June 2019 \\
\hline RECEIVED ON & Thursday, 02 May 2019 \\
\hline \multirow[t]{2}{*}{ ACCEPTED ON } & Friday, 24 May 2019 \\
\hline & $(\mathrm{ccc}) \mathrm{EY}$ \\
\hline LICENSE & $\begin{array}{l}\text { This work is licensed under a Creative Commons Attribution } 4.0 \text { International } \\
\text { License }\end{array}$ \\
\hline JOURNAL & "Investment Management and Financial Innovations" \\
\hline ISSN PRINT & $1810-4967$ \\
\hline ISSN ONLINE & $1812-9358$ \\
\hline PUBLISHER & LLC "Consulting Publishing Company "Business Perspectives" \\
\hline FOUNDER & LLC "Consulting Publishing Company "Business Perspectives" \\
\hline
\end{tabular}

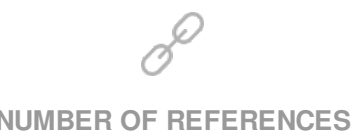

23

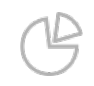

NUMBER OF FIGURES

6

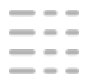

NUMBER OF TABLES

4

(C) The author(s) 2022. This publication is an open access article. 


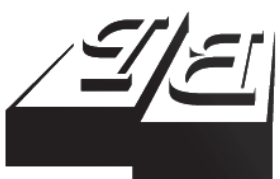

BUSINESS PERSPECTIVES

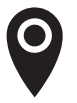

LLC "CPC "Business Perspectives" Hryhorii Skovoroda lane, 10, Sumy, 40022, Ukraine

www.businessperspectives.org

Received on: $2^{\text {nd }}$ of May, 2019 Accepted on: $24^{\text {th }}$ of May, 2019

(C) Ivan Bogatyrev, Vasyl Topchiy, Igor Koropatnik, Oleksandr Kotliarenko, Andrii Kofanov, 2019

Ivan Bogatyrev, Doctor of Law, Professor, University of the State Fiscal Service of Ukraine, Honoured Worker of Science and Technology of Ukraine, Ukraine.

Vasyl Topchiy, Doctor of Law, Professor, University of the State Fiscal Service of Ukraine, Merited Lawyer of Ukraine, Ukraine.

Igor Koropatnik, Doctor of Law, Associate Professor, Kyiv National University named after Taras Shevchenko, Ukraine.

Oleksandr Kotliarenko, Ph.D. Candidate (Law), National Defense University of Ukraine named after Ivan Chernyakhovsky, Ukraine.

Andrii Kofanov, Ph.D. Candidate (Law), Associate Professor, Legal Advisor to the Council of Europe Programme "Decentralization and Territorial Consolidation in Ukraine", National Academy of Internal Affairs, Ukraine.

\section{(c) (i)}

This is an Open Access article, distributed under the terms of the Creative Commons Attribution 4.0 International license, which permits unrestricted re-use, distribution, and reproduction in any medium provided the original work is properly cited.
Ivan Bogatyrev (Ukraine), Vasyl Topchiy (Ukraine), Igor Koropatnik (Ukraine), Oleksandr Kotliarenko (Ukraine), Andrii Kofanov (Ukraine)

\section{PROBLEMS AND PERSPECTIVES FOR ATTRACTING INVESTMENTS IN ECONOMY OF UKRAINE}

\begin{abstract}
The purpose of the article is to study the current problems of investment processes in the conditions of transformation of the Ukrainian economy. The relevance of the research was due to significant changes in political, economic and social processes of Ukraine.

The research was conducted using general scientific and special methods and methods of research, such as theoretical analysis and synthesis, methods of grouping, modeling, comparison, as well as methods of systematization and scientific synthesis, in particular on materials: Ministry of Economic Development and Trade of Ukraine, research conducted by the Doing Business Group of the World Bank, rating of Moody's Investors Service, rating of Global Competitiveness Index 2017/2018 and of European Business Association.

The most actual factors of influence of political, economic, criminal and legislative processes on investment potential of Ukraine were analyzed. It was defined that the economic of Ukraine is characterized by the deficiency of capital, progressive technologies, mutual integration of scientific and industrial spheres, developed management and high-tech production and the recommendations to create favorable conditions for investment were made. Positive changes were noted in creating a legal framework for the promotion, protection of investments and intensification of investment activity in Ukraine.
\end{abstract}

Keywords

JEL Classification government policy, investment potential, investment risks, investment attractiveness, microeconomic policy

\section{INTRODUCTION}

The investment potential of Ukraine against the backdrop of globalization and the intellectualization of the world economy is largely unfulfilled, but it has strong preconditions for development.

Ukraine is one of the largest and richest countries in Europe. It occupies the first place in Europe in the area of arable land and the third largest in the world in terms of black earth. Ukraine is also an industrial country, which ranks second in terms of capacity of the gas transmission system; second and fourth in the world for the export of cast iron and iron ore, respectively; third and fourth in Europe for the power of nuclear power plants and the length of railways. Ukraine belongs to countries with high level of education of the population.

The unstable political system, the crisis phenomena due to the escalation of the military conflict in the East of Ukraine, the slowdown in the fight against corruption, the imperfect legislative system, regulatory barriers are negative factors that hold back the rapid economic growth and shape the negative image of the country as high-risk coun- 
try (Fedorchak, 2017). On the way to overcoming them there is an objective need for long-term investments, which determines the relevance of this study.

World experience shows that the national economies of most countries are not able to quickly and effectively solve their own problems of economic growth (Dzomira, 2017). Independent development, without the attraction and effective use of foreign investment do not bring the desired fast result. In South Korea, Taiwan, Singapore, Hong Kong, over a relatively short period of time, it has managed to create stable economic structures that can dynamically and quickly adapt to the changing global market environment. The volume of attraction of foreign investments depends on the level of economic development of the country.

\section{THEORETICAL BASIS}

In essence, foreign investment contributes to the economic development of the state ensuring the effective use of its national resources, solves the problems of employment, forms the general level of wages, changes the conditions of competition in the host economy, etc. Nowadays, the results of attracting foreign investments affect all aspects of the development of society, changing the country's economic environment, ways of ensuring its existence and development. The scheme of such interaction is shown in Figure 1 (Erokhin, 2016).

Creating favorable conditions for investment, investment attractiveness of the country is an urgent problem that needs urgent resolution, as the inflow of funds into the economy will give an impetus to its stable development.
Ukraine can potentially be one of the leading foreign investment countries, but this activity is characterized by high level of uncertainty and risks, which requires a continuous study of investment processes.

The legislation of Ukraine states that investments are all types of property and intellectual property that are invested in objects of entrepreneurial and other types of activity, which results in the creation of profit or social effect (Beattie, 2019).

At the same time, there is no legally defined concept of "investment potential", and among scientists there are discussions about a unified interpretation of the category "investment potential". Many domestic scientists and researchers propose a number of approaches to the definition of the essence and composition of investment potential

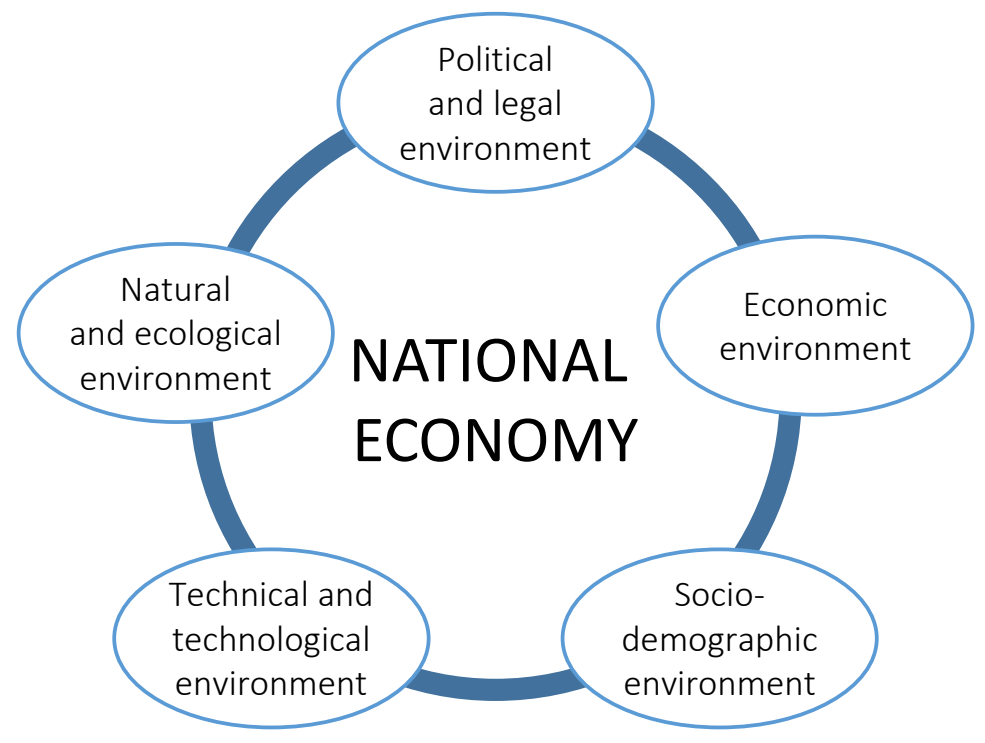

Figure 1. Scheme of influence of foreign investments on different sides of life 
(Melnyk et al., 2011; Kucheruk, 2008; Silyukova, 2013; Kharlamova et al., 2009).

An analysis of the views of scholars and researchers on this category leads to the conclusion that the country's investment potential is a combination of opportunities for attracting investment capital to the state's economy to create favorable conditions for development and the most expedient use of it, leading to economic growth.

First of all, it is necessary to study the state of the economy and investment activity and to determine the factors influencing it, as with the development of investment potential there is an opportunity to create new jobs, to modernize production, to increase the volume and quality of production, to improve the financial infrastructure and to improve the Ukrainian economy. In general, investment processes in Ukraine have their own specifics.

\section{RESULTS}

Within the state, investment resources are gross savings in the gross domestic product, created for the year, less current and personal consumption.

Investigating this issue, we came to the conclusion that the real gross domestic product (GDP) in 2018 compared to 2017 increased by $3.3 \%$, but did not reach the level of 2011 (Figure 2). Nominal GDP was UAH 3,558.7 billion, and GDP per capita - 84,190 UAH (without taking into account the occupied territories (Crimea, Sevastopol, parts of Donbas)). The calculations of GDP are based on the international standards of the National Accounts System 2008 and the European System of National and Regional Accounts 2010.

The conducted studies indicate that Ukraine's economy was undergoing dramatic changes in 20142015 as a result of the annexation of the Autonomous Republic of Crimea, armed aggression in the territories of certain districts of Donetsk and Luhansk regions. The country suffered losses in production facilities, infrastructure destruction, as well as the associated shortages of energy resources and raw materials, logistical problems and the shutdown of key industrial enterprises in the east, coupled with the accumulated internal structural development problems (significant dependence on trade links with one country) and the deterioration of the foreign economic situation caused the deployment of an economic crisis characterized by a loss of a part of the development potential:

- the reduction of GDP in 2014 was $6.6 \%$, and in 2015 - another $9.8 \%$, including industrial production $-10.1 \%$ and $13 \%$, respectively. Negative contribution of Donetsk and Luhansk regions in 2014 to industrial production was "minus" 7.6\%, for the year 2015 - "minus" $7.8 \%$.

- the national currency devaluated by 3 times during 2014-2015, and the peak of consumer price growth was reached in April 2015 60.9\% (as of April 2014). Overall, consumer price growth in 2014 was $24.9 \%$ (as calculated by December of the previous year), in 2015 $-43.3 \%$;

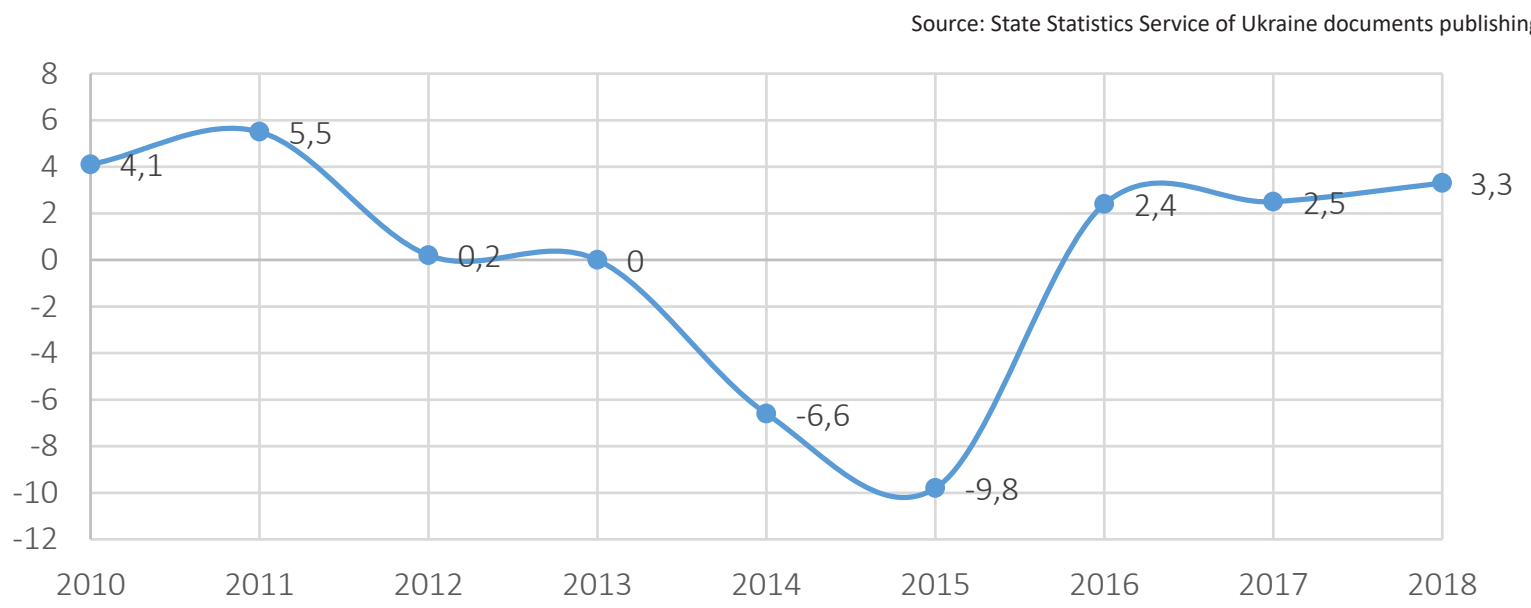

Figure 2. Changes in real gross domestic product (\% in the previous year) 


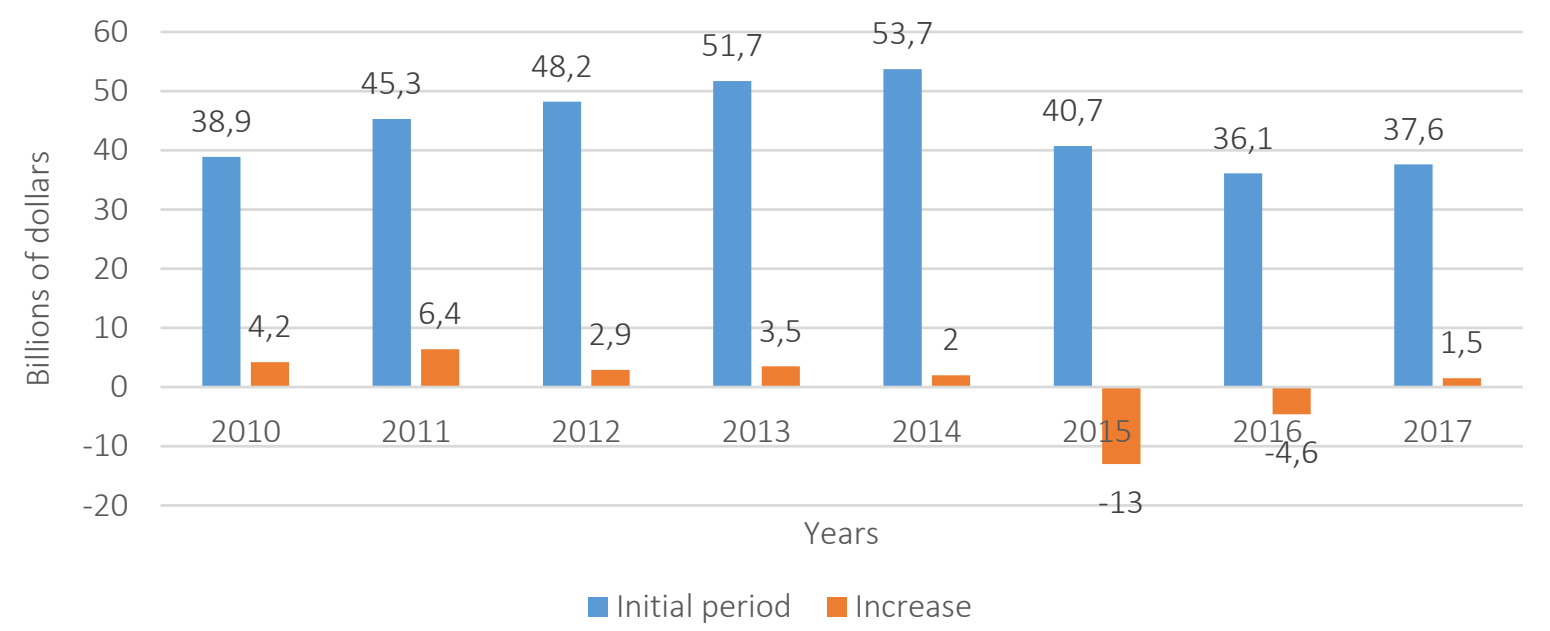

Figure 3. Dynamics of volume of direct foreign investments in the economy of Ukraine from January 1, 2010 to December 1, 2017

- there were processes of investment contraction and deterioration of the balance of payments. In 2014, the volumes of exports of goods and services decreased by $19.9 \%$ in comparison with the previous year, by $26.9 \%$ in 2015 , in particular, exports of goods and services to the Russian Federation in 2014 decreased by $42.2 \%$, in 2015 , by $45.4 \%$, the volume of imports of goods and services in Ukraine as a whole decreased by $28.1 \%$ and $28.3 \%$, respectively. According to the Ministry of Economic Development's indicative estimates, the decrease in exports of goods and services to the Russian Federation is estimated at a "minus" 5.7\% and "minus" 5.6\% GDP in 2014 and 2015, respectively (Reports from the Ministry of Economic Development, 2014, 2015).

Due to the chosen course on European integration and the fundamental reformation of the economy, since 2016, Ukraine has been experiencing gradual economic growth in the face of constant new challenges: trade restrictions (food embargo), restrictions on international transit transportation of goods from Ukraine to the territory of the Republic of Kazakhstan and the Kyrgyz Republic through the territory of the Russian Federation, as well as the deterioration of the external pricing situation on world markets.

Another trial in 2017 was the temporary suspension of cargo movement through a line of collision with railways and motorways within Donetsk and
Luhansk regions in response to aggravation of hostilities. The operation of this factor complicated the operation of the mining and metals complex and energy. At the same time, the growth of industrial production at the end of the year amounted to $0.4 \%$ and was largely due to the growth of machine building in response to the continued expansion of domestic investment demand, including domestic defense industries (Ilyash, Dzhadan, \& Ostasz, 2018). Overall, GDP growth was 2.5\%, and inflation was kept within safe limits $-13.7 \%$ per year.

In 2019, the Russian government is forbidden to export Russian oil and petroleum products to Ukraine and a separate category of goods, including coal, oil and petroleum products, can be exported to Ukraine only on the basis of individual permits.

Since the second half of 2014, there has been a decline in direct foreign investment in the period of a sharpening financial and economic crisis in Ukraine. Thus, in 2015, compared with the previous volume of direct foreign investments, there has been a decrease by $24.2 \%$, which led to negative growth, that is, "minus" USD 13 billion in the economy of Ukraine. In 2017, compared with 2016, there was a slight recovery in investment activity and the volume of foreign investment increased by USD 1,5 billion.

In percentage terms, the main investor from all 121 countries that invests in the national economy is Cyprus, which is $25.6 \%$ of the total amount 
Table 1. The volume of direct foreign investments in the economy of Ukraine

\begin{tabular}{|c|c|c|c|c|c|c|}
\hline \multirow{3}{*}{$\frac{\text { Year }}{2002}$} & \multicolumn{6}{|c|}{ Direct foreign investment in Ukraine from 2002 to 2018 (USD million) } \\
\hline & \multicolumn{2}{|c|}{ Into Ukraine } & \multicolumn{2}{|c|}{ From Ukraine } & \multicolumn{2}{|c|}{ Balance } \\
\hline & 693 & $\mathrm{~N} / \mathrm{A}$ & -5 & N/A & +698 & $\mathrm{~N} / \mathrm{A}$ \\
\hline 2003 & 1,424 & 731 & 13 & 18 & $+1,411$ & $102.1 \%$ \\
\hline 2004 & 1,715 & 291 & 4 & -9 & $+1,711$ & $21.3 \%$ \\
\hline 2005 & 7,808 & 6,093 & 275 & 271 & $+7,533$ & $340.3 \%$ \\
\hline 2006 & 5,604 & $-2,204$ & -133 & -408 & $+5,737$ & $-23.8 \%$ \\
\hline 2007 & 9,891 & 4,287 & 673 & 806 & $+9,218$ & $60.7 \%$ \\
\hline 2008 & 10,913 & 1,022 & 1,010 & 337 & $+9,903$ & $7.4 \%$ \\
\hline 2009 & 4,816 & $-6,097$ & 162 & -848 & $+4,654$ & $-53.0 \%$ \\
\hline 2010 & 6,495 & 1,679 & 736 & 574 & $+5,759$ & $23.7 \%$ \\
\hline 2011 & 7,207 & 712 & 192 & -544 & $+7,015$ & $21.8 \%$ \\
\hline 2012 & 8,401 & 1,194 & 1,206 & 1,014 & $+7,195$ & $2.6 \%$ \\
\hline 2013 & 4,499 & $-3,902$ & 420 & -786 & $+4,079$ & $-43.3 \%$ \\
\hline $2014^{*}$ & 410 & $-4,089$ & 111 & -309 & +299 & $-92.7 \%$ \\
\hline 2015 & 2,961 & 2,551 & -51 & -162 & $+3,012$ & $907.4 \%$ \\
\hline 2016 & 3,284 & 323 & 16 & 67 & $+3,268$ & $8.5 \%$ \\
\hline 2017 & 2,202 & $-1,082$ & 8 & -8 & $+2,194$ & $-32.9 \%$ \\
\hline 2018 & 2,355 & 153 & -5 & -13 & $+2,360$ & $7.6 \%$ \\
\hline
\end{tabular}

Note: * From 2014 - without taking into account the occupied territories (Crimea, Sevastopol, parts of Donbas).

of investments. Most of the investor countries are ities - 6\%; information and telecommunications members of the European Union: the Netherlands, $-5.4 \%$; other types of economic activity $-10.4 \%$. Germany, France, Austria, Luxembourg and the United Kingdom.

Table 2. Direct investments (share capital) from the countries of the world into the Ukrainian economy

\begin{tabular}{|c|c|c|c|c|}
\hline \multirow[b]{2}{*}{ Country } & \multicolumn{4}{|c|}{$\begin{array}{l}\text { Volume of direct investments } \\
\text { (million USD) }\end{array}$} \\
\hline & 2016 & 2017 & 2018 & $\begin{array}{c}\text { As of } \\
\text { December } \\
31,2018\end{array}$ \\
\hline Cyprus & $9,894.8$ & $8,785.5$ & $8,932.7$ & $8,879.5$ \\
\hline Netherlands & $6,090.3$ & $6,028.4$ & $6,395.0$ & $7,060.9$ \\
\hline $\begin{array}{l}\text { United Kingdom of } \\
\text { Great Britain and } \\
\text { Northern Ireland }\end{array}$ & $1,785.2$ & $1,947.0$ & $1,944.4$ & $1,955.9$ \\
\hline Virgin Islands (British) & $1,715.0$ & $1,682.5$ & $1,358.4$ & $1,311.4$ \\
\hline Germany & $1,604.9$ & $1,564.2$ & $1,682.9$ & $1,668.2$ \\
\hline Switzerland & $1,391.0$ & $1,436.9$ & $1,515.9$ & $1,540.7$ \\
\hline
\end{tabular}

The leading spheres of economic activity of Ukraine by volume of attraction of investments as of January 1, 2017 are: industry $-28.7 \%$, from it, the processing industry makes $20.7 \%$; financial and insurance activities - 26.4\%; wholesale and retail trade - 13.3\%; real estate transactions - 9.8\%; professional, scientific, and technical activ-

The inflow of direct investments into the Ukrainian economy by sectors in 2016 and 2017 shows an almost unchanged distribution of investment income.

A comparison of the distribution of direct investment in the context of regions of Ukraine gives grounds for concluding that Kyiv is a leader where, as of January 1,2017, 60\% of the total investment is invested. Regarding the regions, Dnipropetrovsk $9.3 \%$, Kyiv $-4 \%$, Odesa $-3.6 \%$, Donetsk $-3.2 \%$ are leading in attracting the investment. Low investment attractiveness and undiscovered investment potential are observed in Ternopil and Chernivtsi regions.

In 2018, GDP growth accelerated to $3.2 \%$, and inflation in the consumer market slowed down to unequivocal numbers for the first time after 2013 and amounted to $9.8 \%$ at the rate December 2017 to December 2018. The situation with capital investment has improved, but to small extent.

The most rational and effective form of foreign investment foreign is direct investment, i.e. 


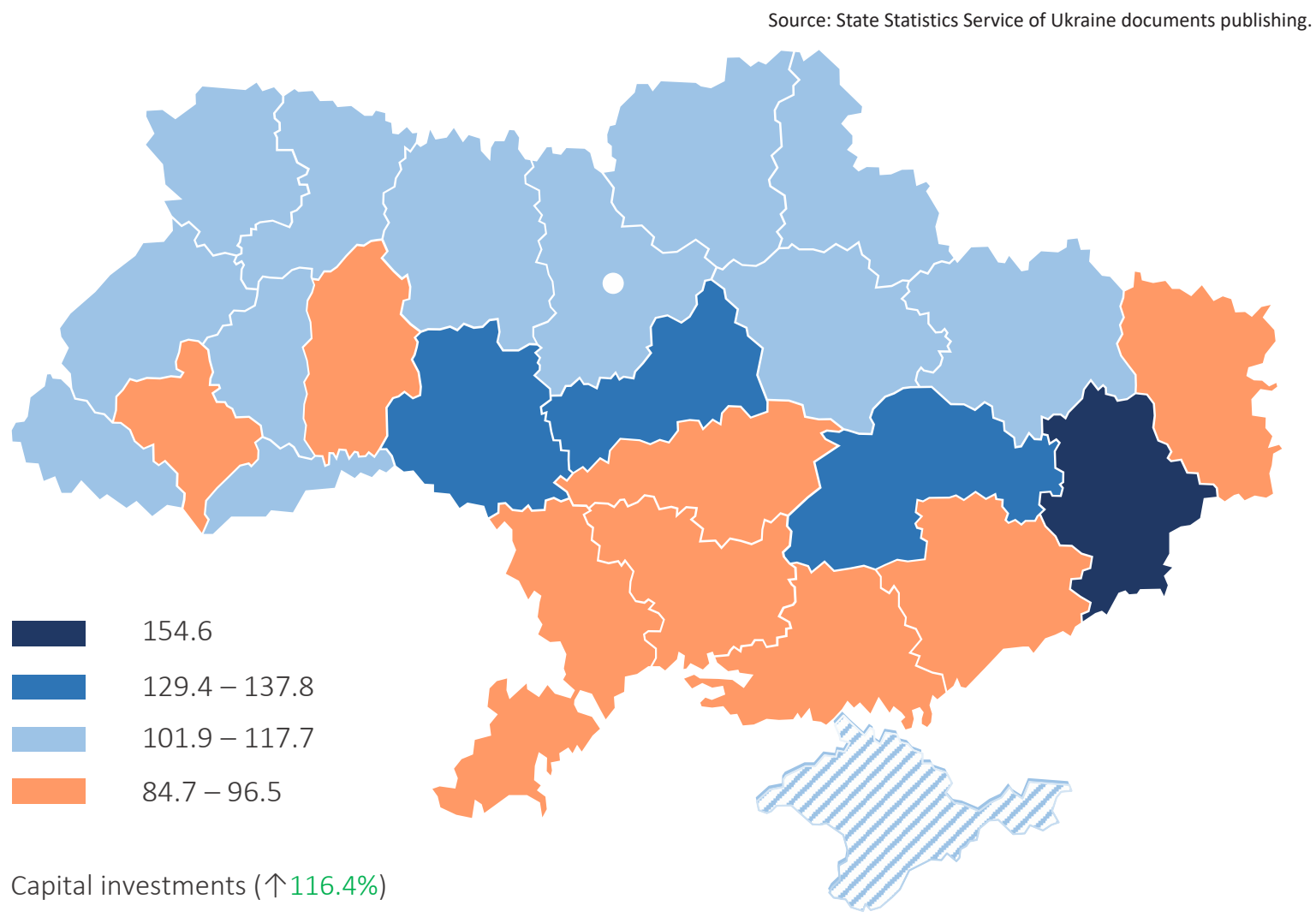

Acquisition of direct investment (share capital) in Ukraine

(an incremental result from the beginning of the year)

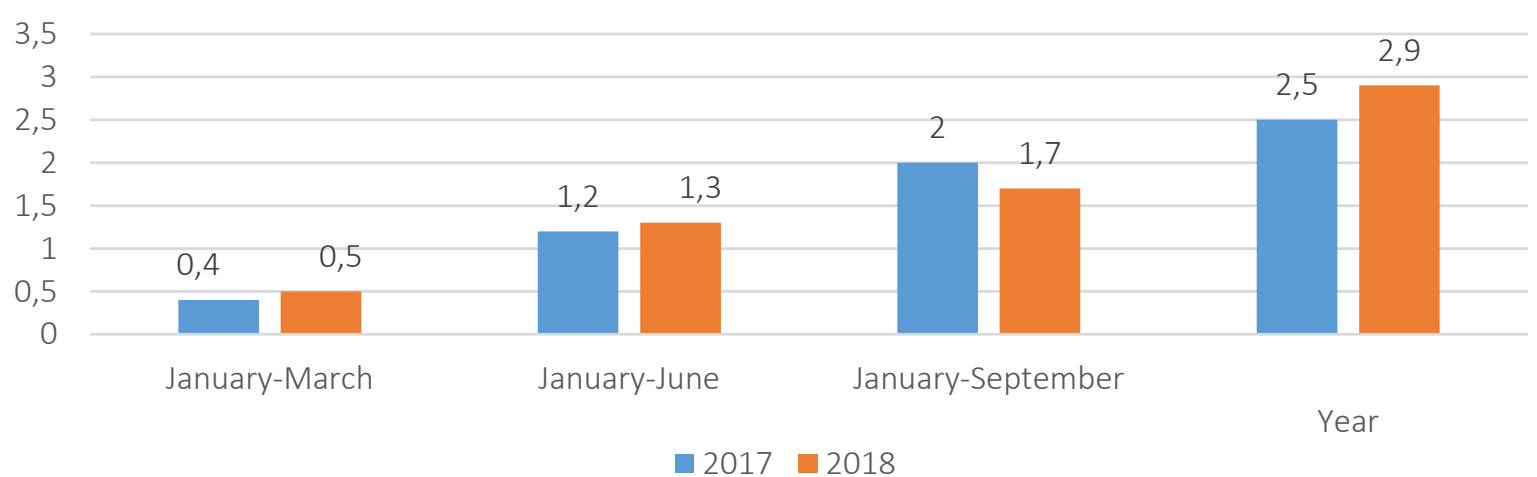

Figure 4. Capital investment and direct investment (share capital in Ukraine as a result of the beginning of 2018)

long-term investments into the national economy. Foreign direct investments are the investments that cause long-term interest in an enterprise operating outside the investor's economy. According to the IMF methodology, foreign direct investments are foreign investments in the amount of more than $40 \%$ of the authorized capital, which gives the interested party the right to participate in the management of the enterprise (Koval, 2013).
Foreign direct investment is a direct investment made by foreign (international) operators in the legal entities of a particular country (Pylypiv, 2011).

In January-March 2018, foreign investors from 76 countries invested in the Ukrainian economy USD 1151.0 million in direct investments (equity).

The volume of attracted foreign direct investment (share capital) in the economy of Ukraine as of 
Table 3. Capital investment by sources of financing for 2010-2017* (UAH million)

\begin{tabular}{|c|c|c|c|c|c|c|c|c|}
\hline \multirow{2}{*}{$\begin{array}{c}\text { Total, including at } \\
\text { the expense of }\end{array}$} & 2010 & 2011 & 2012 & 2013 & 2014 & 2015 & 2016 & 2017 \\
\hline & $18,0575.5$ & $241,286.0$ & $273,256.0$ & $249,873.4$ & $219,419.9$ & $273,116.4$ & $359,216.1$ & $448,461.5$ \\
\hline $\begin{array}{l}\text { The state budget } \\
\text { funds }\end{array}$ & $10,223.3$ & $17,376.7$ & $16,288.3$ & $6,174.9$ & $2,738.7$ & $6,919.5$ & $9,264.1$ & $15,295.2$ \\
\hline $\begin{array}{l}\text { Funds of local } \\
\text { budgets }\end{array}$ & $5,730.8$ & $7,746.9$ & $8,555.7$ & $6,796.8$ & $5,918.2$ & $14,260.0$ & $26,817.1$ & $41,565.5$ \\
\hline $\begin{array}{l}\text { Own funds of } \\
\text { enterprises and } \\
\text { organizations }\end{array}$ & $111,371.0$ & $147,569.6$ & $171,176.6$ & $165,786.7$ & $154,629.5$ & $184,351.3$ & $248,769.4$ & $310,061.7$ \\
\hline $\begin{array}{l}\text { Bank loans and other } \\
\text { loans }\end{array}$ & $22,888.1$ & $36,651.9$ & $39,724.7$ & $34,734.7$ & $21,739.3$ & $20,740.1$ & $27,106.0$ & $29,588.9$ \\
\hline $\begin{array}{l}\text { Funds of foreign } \\
\text { investors }\end{array}$ & $3,723.9$ & $5,038.9$ & $4,904.3$ & $4,271.3$ & $5,639.8$ & $8,185.4$ & $9,831.4$ & $6,206.4$ \\
\hline $\begin{array}{l}\text { Funds of the } \\
\text { population for } \\
\text { building }\end{array}$ & $18,885.9$ & $17,589.2$ & $22,575.5$ & $24,072.3$ & $22,064.2$ & $31,985.4$ & $29,932.6$ & $32,802.5$ \\
\hline $\begin{array}{l}\text { Other sources of } \\
\text { funding }\end{array}$ & $7,752.5$ & $9,312.8$ & $10,030.9$ & $8,036.7$ & $6,690.2$ & $6,674.7$ & $7,495.5$ & $12,941.3$ \\
\hline
\end{tabular}

Note: * Information excludes the temporarily occupied territories.

April 1, 2018 amounted to USD 32,751 million*.

Investments are diverted into already developed areas of economic activity.

As of April 1, 2018, the most important volumes of direct investment income were directed to industrial enterprises $-33.6 \%$, and institutions and organizations engaged in wholesale and retail trade; repair of motor vehicles and motorcycles $-15.6 \%$.

An important component of the analysis of investment processes is the study of the geographical structure of attracted investments, which is formed under the influence of many factors, among the main being the development of foreign economic relations with strategic partners and the need for diversification of international investment activities. Today, the main strategic economic partners are the EU member states.

The main investor countries include Cyprus - 28.1\%, the Netherlands - 20.6\%, the United Kingdom $6.1 \%$, Germany $-5.5 \%$, Austria $-3.4 \%$, the Virgin Islands (Brit.) $-4.1 \%$, and Switzerland $-4.7 \%$.

The volume of development of capital investments of enterprises of Ukraine in January-March 2018 amounted to UAH 89 billion, which is $37.4 \%$ more than the volume of capital investments for the corresponding period of 2017.
In the leading spheres of economic activity, in terms of development of capital investments, in 2017 there remain: industry - 35.9\%, construction $-11.7 \%$, agriculture, forestry and fisheries - $12.0 \%$, information and telecommunications $8.9 \%$, wholesale and retail trade; repair of motor vehicles and motorcycles $-8.1 \%$, transport, warehousing, postal and courier activities $-9.2 \%$, public administration and defense; obligatory social insurance $-2.1 \%$.

The own funds of enterprises and organizations the main source of financing of capital investments remains, due to which in January-March $2018,76.2 \%$ of investments were mastered.

The share of bank loans and other loans in total investment was $8.4 \%$.

At the expense of the state and local budgets, 4.2\% of capital investments was absorbed. The share of funds from foreign investors amounted to $0.3 \%$ of all investments, and the share of households in housing construction was $8.2 \%$. Other sources of funding are $2.7 \%$.

So, Ukraine remains attractive for investment, at the same time, it is not isolated from world processes, it is sufficiently integrated into the world economy and the violation of macrostability in foreign markets has its echo in Ukraine. 


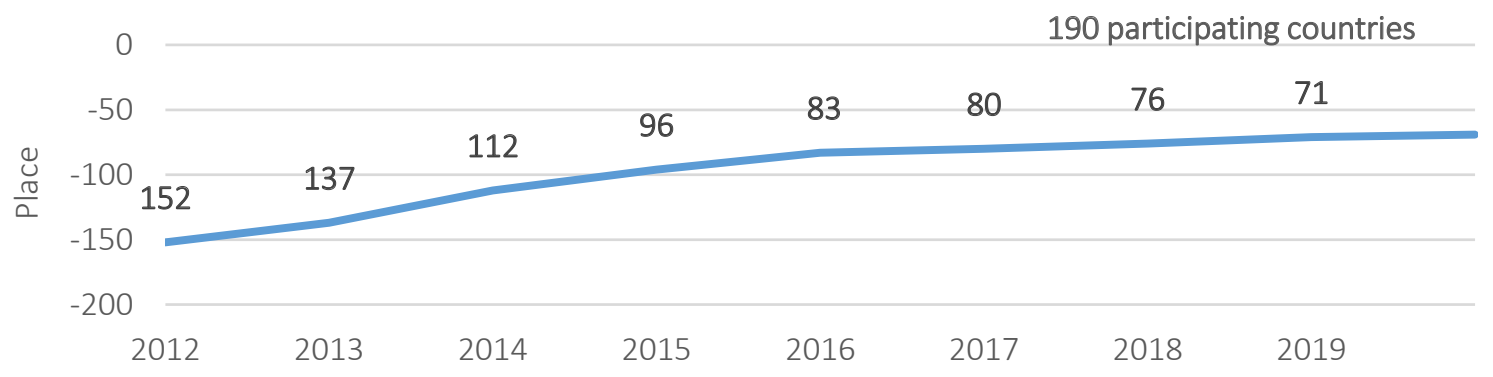

Figure 5. Ukraine in the Doing Business Rating in 2012-2019

The place occupied by the country in international ratings best reflects the state and dynamics of the domestic economy. Information provided by the ratings can serve as a basis for assessing the level of investment potential and relative risk level in different countries, and can serve as a benchmark for foreign investors and government authorities of the country when developing investment policies.

The Doing Business 2018 Survey shows that Ukraine has risen by +4 points and ranked 76 th. And in the first quarter of 2019, it rose to +5 points and ranked $71^{\text {st }}$ from 190 countries (Figure 5). Ukraine has shown the greatest progress in the following rankings: +105 points (140th for 35 th place) for the component "obtaining construction permits" due to reduction of share participation in Kyiv from 10 to $2 \%$ and reduction of the cost of technical services; +41 point on "payment of taxes" for the reduction and unification of the rate of a single social contribution.
Other criteria (tax payment system, business registration, access to electricity, access to credit, insolvency) restrain Ukraine's progress in the rating - their performance has deteriorated.

Also, it should be noted that in the ranking of agency Moody's Investors Service, Ukraine has improved its credit rating in the international economic list. It has changed from Caa3 to Caa2, which means changing the forecast from "stable" to "positive". The improvement of the indicators was influenced by the implementation of structural reforms in Ukraine, which helped the country to cope with the debt burden and improve its position on foreign markets.

Rating and Investment Information Agency has raised the rating of Ukraine in foreign currency to the level of "SSS +" from the level of "SSS" and a stable forecast is confirmed.

In the Global Competitiveness Index (GCI) 2017/2018 ranking, Ukraine has improved its

Table 4. Key indicators of Ukraine in the Doing Business Rating in 2018-2019

Source: Formed based on the data from State Statistics Service of Ukraine.

\begin{tabular}{|c|c|c|c|c|}
\hline Key indicators & $\begin{array}{c}\text { Doing Business } \\
\text { Rating } 2017\end{array}$ & $\begin{array}{l}\text { Doing Business } \\
\text { Rating } 2018\end{array}$ & $\begin{array}{l}\text { Doing Business } \\
\text { Rating } 2019\end{array}$ & Changes \\
\hline Ease of doing business & 80 & 76 & 71 & +5 \\
\hline According to indicators & N/A & N/A & N/A & N/A \\
\hline Registration of enterprises & 20 & 52 & 56 & -4 \\
\hline Enforcement of contracts & 81 & 82 & 57 & +25 \\
\hline Lending & 20 & 29 & 32 & -3 \\
\hline Protection of investors & 70 & 81 & 72 & +9 \\
\hline Settling the issue of insolvency & 150 & 149 & 145 & +4 \\
\hline Connection to the power grid & 130 & 128 & 135 & -7 \\
\hline Obtaining building permits & 140 & 35 & 30 & +5 \\
\hline Property registration & 63 & 64 & 63 & +1 \\
\hline International trade & 115 & 119 & 78 & +41 \\
\hline Taxation & 84 & 43 & 54 & -11 \\
\hline
\end{tabular}




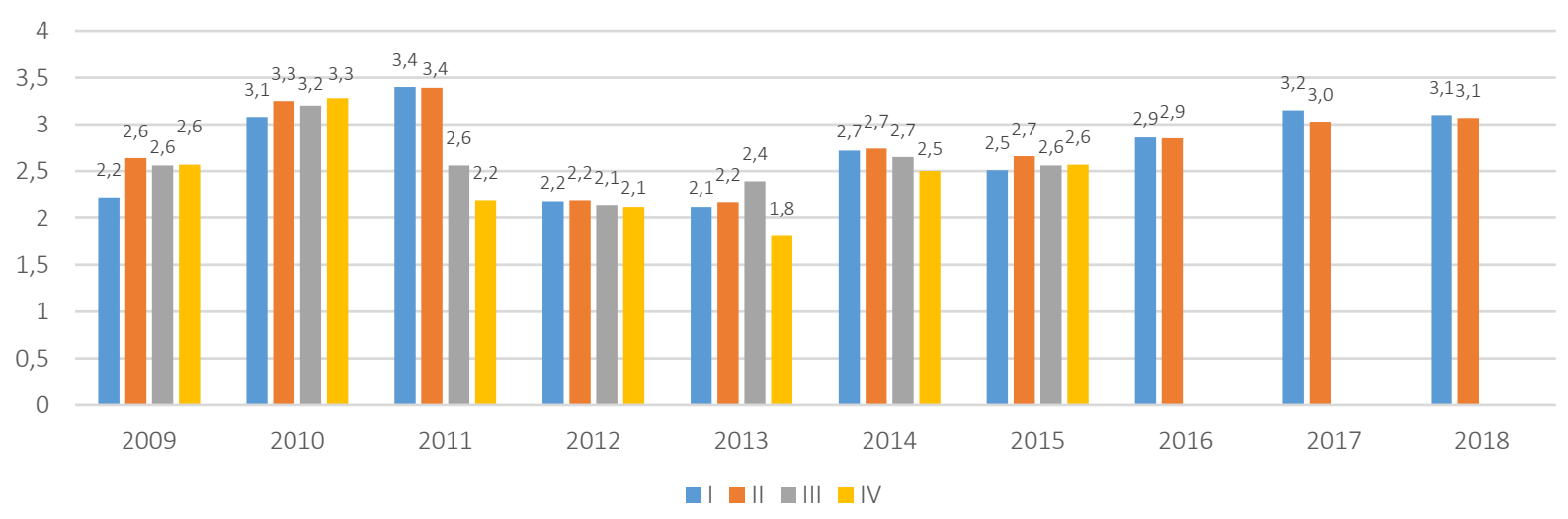

Figure 6. Investment Attractiveness Index of Ukraine

position by 4 points and ranked 81st out of 137 countries surveyed (in GCI 2016/2017, ranked 85 among 138 countries) (Reports from the Ministry of Economic Development of Ukraine, 2017, 2018). The quality of roads and ports of Ukraine is estimated by the smallest number of points.

In the first half of 2017, the Investment Attractiveness Index of Ukraine left the negative plane for the first time since 2011 with an indicator of 3.15 points. Today, the Investment Attractiveness Index of Ukraine by the version of top managers of affiliated companies of the European Business Association remains in a neutral plane. But at the end of 2018, this figure was 3.03 points on a 5 -point scale (Likert scale).

Top managers of Association member companies mark the liberalization of currency legislation, the relative stability of the national currency and the level of inflation, the implementation of effective methods of countering raider attacks, economic recovery and the development of electronic services, continuous dialogue of power with business.

Among the main factors or investment risks that restraint the influx of foreign direct investment into Ukraine should be: ongoing military actions on the territory of Ukraine; unresolved issue of free circulation of land; inhibition of large privatization; separate restrictions on capital movements; increase in the level of economic crime, distrust of investors to the judicial system (Trudeau, 2019). The reform of the Ukrainian law enforcement sys- tem, the low level of crime detection (especially in the economic sphere) also negatively affect the investment attractiveness of the state. According to the data from the Ministry of Internal Affairs of Ukraine, in 1992 , there were 36,860 crimes in the economic sphere, by 2018 the number of crimes increased by $297.5 \%$ and amounted to 109,825 crimes (Kofanova et al., 2019).

Political uncertainty is connected with the 2019 elections of the Head of State and new parliament, which will result in the reformation of the Government. Investors also noted a high level of corruption $(78 \%$ of respondents are critically dissatisfied with the state of affairs), increase in the level of economic crime $-74 \%$, lack of land reform $-66 \%$ and shadow economy $-65 \%$.

Currently, 53\% of company executives believe that the business climate in Ukraine will remain unchanged in the first half of 2019. And despite this, $42 \%$ believe that Ukraine is still a profitable investment market in the next six months.

Taking into account the military, informational, economic and political aggression against Ukraine, promotion of Ukraine in the abovementioned ratings is an indicator of the country's enormous potential.

Improvement of the investment climate in Ukraine by improving the existing legal and organizational framework will help to increase the competitiveness of the domestic economy. 


\section{CONCLUSION}

Summarizing the results of the study, we can make the following conclusions. It is established that in the scientific literature, there is no single vision in determining investment risks and investment potential.

The conducted studies showed that Ukraine's economy was undergoing dramatic changes in 2014-2015 as a result of the annexation of the Autonomous Republic of Crimea, armed aggression in the territories of certain districts of Donetsk and Luhansk regions. The country suffered losses in production facilities, infrastructure destruction, as well as the associated shortages of energy resources and raw materials, logistical problems and the shutdown of key industrial enterprises in the east.

The analysis of international competitiveness ratings allowed to identify risks and assess the investment potential of Ukraine in the near future, to establish that along with the problems, there are a number of advantages that are potential opportunities for increasing the investment attractiveness of the domestic economy for foreign investors. Among them are the following:

- advantageous geopolitical location;

- high level of natural resource availability;

- high-skilled workforce;

- capacious consumer market.

By analyzing foreign investment by type of activity, it can be seen that they are diverted into already developed areas of economic activity. In particular, in industry: processing, mining, production and distribution of electricity, gas and water, etc. Instead, foreign capital is being overstepped by high-tech industries such as engineering, aviation, electronics, etc., although these industries in Ukraine are most in need of capital investment to modernize, intensify and innovate the development.

\section{REFERENCES}

1. Beattie, A. (2019). Defining the 3 types of investments. Investopedia: Dotdash. Retrieved from https:// www.investopedia.com/articles/ younginvestors/10/what-is-aninvestment.asp

2. Dzomira, Sh. (2017). Governance and financial health risk in an emerging economy's public sector. Public and Municipal Finance, 6(1), 83-87. http://dx.doi.org/10.21511/ pmf.06(1).2017.09

3. Erokhin, S. (2016). Проблеми залучення іноземних інвестицій в економіку України [Problemy zaluchennia inozemnykh investytsii v ekonomiku Ukrainy]. Hlobalni ta natsionalni problemy ekonomiky, 12, 73-76.

4. European Securities and Markets Authority (ESMA) (2018). Trends, Risks and Vulnerabilities (Report No. 2) (112 p.). Retrieved from https://www.esma.europa.eu/sites/ default/files/library/esma_50-165632_report_on_trends_risks_and_ vulnerabilities_no.2_2018.pdf

5. Fedorchak, O. (2017). Інвестиційні ризики та інвестиційний потенціал України: державно-управлінський аспект [Investytsiini ryzyky ta investytsiinyi potentsial Ukrainy: derzhavno-upravlinskyi aspekt]. Derzhavne upravlinnia ta mistseve samovriaduvannia, 2(33), 84-93. Retrieved from http:// www.irbis-nbuv.gov.ua/cgi-bin/ irbis_nbuv/cgiirbis_64.exe?I21 $\mathrm{DBN}=\mathrm{LINK} \& \mathrm{P} 21 \mathrm{DBN}=\mathrm{UJRN}$ $\& Z 21 \mathrm{ID}=\& S 21 \mathrm{REF}=10 \& S 21 \mathrm{C}$ $\mathrm{NR}=20 \& S 21 \mathrm{STN}=1 \& \mathrm{~S} 21 \mathrm{FMT}$ $=$ ASP_meta\&C21COM=S\&2_ $\mathrm{S} 21 \mathrm{P} 03=\mathrm{FILA}=\& 2$ S21STR=dums_2017_2_13

6. Ilyash, O., Dzhadan, I., \& Ostasz, G. (2018). The influence of the industry's innovation activities indices on the industrial products' revenue of Ukraine. Economics and Sociology, 11(4), 317-331. http://dx.doi.org/10.14254/2071789X.2018/11-4/21

7. International Monetary Fund (2018). Public Investment Management Assessment - Review and Update Electronic copies of IMF Policy Papers. Washington. Retrieved from http://www.imf. org/external/pp/ppindex.aspx

8. Investment activities in Ukraine (2019). Official website of the Ministry of Economic Development and Trade of Ukraine. Retrieved from http:// www.me.gov.ua/

9. Investment economic activity of Ukraine (2017). Official website of the State Statistics Service of Ukraine. Retrieved from http:// www.ukrstat.gov.ua 
10. Kharlamova, G. (2009). Індикатори інвестиційної привабливості України [Indykatory investytsiinoi pryvablyvosti Ukrainy]. Aktualni problemy ekonomiky, 3, 45-56.

11. Kofanova, O., Tereshchenko, Yu., Kutsyi, R., Morhun, N., \& Gushchyn, O. (2019). Actual situation of computer crime in the credit and financial sphere of Ukraine (modern aspects). Banks and Bank Systems, 14(1), 172180. http://dx.doi.org/10.21511/ bbs.14(1).2019.15

12. Koval, G. (2013). Прямі іноземні інвестиції в країнах із перехідною економікою (на прикладі Польщі) [Priami inozemni investytsiii v krainakh iz perekhidnoiu ekonomikoiu (na prykladi Polshchi]. Ukraina ta Polshcha: mynule, sohodennia, perspektyvy, 2, 49-53. Retrieved from http://nbuv.gov.ua/UJRN/ UPmcp_2013_2_14

13. Kucheruk, G., \& Vovk, O. (2008). The economic justification of the integrated assessment of the investment potential of the airline. Economy. Finances. Right, 5, 6-7. Retrieved from http://opac.mk.ua

14. Lanovy, V. (2015). Анатомія кризи української економіки [Anatomiia kryzy ukrainskoi ekonomiky]. Ekonomichna pravda. Retrieved from http:// www.epravda.com.ua/publications/2015/06/16/546489

15. Luciv, B., \& Stachyshyn, T. (2009) Інвестиційний потенціал банківської системи України [Investytsiinyi potentsial bankivskoi systemy Ukrainy]. Fi- nansy Ukrainy, 9, 67-77. Retrieved from http://nbuv.gov.ua/UJRN/ Fu_2009_9_8

16. Melnyk, A., Vasina, A., Zhyluk, T., \& Popovich, T. (2011). Національна економіка [Natsionalna ekonomika] (463 p.). Kyiv: Znannia. Retrieved from https://pidruchniki. com/1584072041779/ekonomika/ natsionalna_ekonomika

17. National Bank of Belgium (2017). Public Investments: Analysis \& Recommendations (Report) (34 p.). Retrieved from https://www.nbb. be/doc/ts/publications/other/Report_public_investments_en.pdf

18. Nechitaylo, U. (2011). Iнвестиційний потенціал та інвестиційний клімат: особливості формування та співвідношення [Investytsiinyi potentsial ta investytsiinyi klimat: osoblyvosti formuvannia ta spivvidnoshenia]. Naukovyi visnyk Uzhhorodskoho universytetu (Seriia "Ekonomika"), 2(32), 97103. Retrieved from https://dspace. uzhnu.edu.ua/jspui/bitstream/lib/ $5222 / 1 / \%$ D0\%86\%D0\%9D\%D0\% 92\%D0\%95\%D0\%A1\%D0\%A2\% D0\%98\%D0\%A6\%D0\%86\%D0\%9 9\%D0\%9D\%D0\%98\%D0\%99\%20 \%D0\%9F\%D0\%9E\%D0\%A2\% D0\%95\%D0\%9D\%D0\%A6\% D0\%86\%D0\%90\%D0\%9B\%20 \%D0\%A2\%D0\%90\%20\%D0\%86\% D0\%9D\%D0\%92\%D0\%95\%D0\% A1\%D0\%A2\%D0\%98\%D0\%A6\% D0\%86\%D0\%99\%D0\%9D\%D0\% 98\%D0\%99\%20\%D0\%9A\%D0\%9 B\%D0\%86\%D0\%9C\%D0\%90\%D 0\%A2.pdf
19. Official website of the LIGA Information and Legal System (n.d.). Doing Business-2019: Украина поднялась на 5 позиций [Doing Business-2019: Ukraina podnyalas na 5 pozitsiy]. Retrieved from https://biz.liga.net/ekonomika/all/novosti/doing-business-2019-ukraina-podnyalas-na5-pozitsiy

20. Silyukova, S. (2013). Розвиток інвестиційного потенціалу регіону як об'єкт державного регулювання [Rozvytok investytsiinoho potentsialu rehionu yak obiekt derzhavnoho rehuliuvannia]. Publichne upravlinnia: teoriia ta praktyka, 1(13), 140-146. Retrieved from http://www.kbuapa. kharkov.ua/e-book/putp/2013-1/ doc/3/05.pdf

21. State Statistics Service of Ukraine documents publishing (n.d.). Retrieved from http://ukrstat.org/en

22. Trudeau, M. (2019). What is investment risk? Which? Financial Services Limited. Retrieved from https://www.which.co.uk/money/ investing/how-investing-works/investment-risks--the-basics/whatis-investment-risk-ammz70z8tx1s

23. United Nations (2009). Public Investment: Vital for Growth and Renewal, but should it be a Countercyclical Instrument? New York and Geneva.

24. World Bank Group (2019). Doing Business 2019: Training for Reform (16th ed.). Retrieved from http:// russian.doingbusiness.org/content/dam/doingBusiness/media/ Annual-Reports/English/DB2019report_web-version.pdf 